\title{
CHARACTERIZATION OF A NATURAL ANTIBODY IN NORMAL GUINEA-PIG SERUM REACTING WITH HOMOLOGOUS SPERMATOZOA
}

\author{
M. H. JOHNSON \\ Physiological Laboratory, University of Cambridge \\ (Received 12th February 1968)
}

It has been known for many years that fresh serum from non-immunized animals causes lysis and immobilization of spermatozoa of some species (Metchnikoff, 1900) and complement is evidently involved in these reactions (Chang, 1947). Complement is usually fixed during antibody-antigen reactions, and later experiments, using complement fixation (Edwards, 1960), immune fluorescence (Beck, Edwards \& Young, 1962; Symons, 1967), mixed conglutination (Lachmann, Sell \& Spooner, 1965) and mixed antiglobulin (Edwards, 1967), indicated that a complement-fixing antibody might be involved in the antispermatozoal activity of serum. Fresh normal serum also lyses the germinal cells of the testis (Spooner, 1964), and this reaction can be detected by mixed conglutination (Lachmann et al., 1965). In contrast with these observations, Brown, Glynn \& Holborow (1963), Pokorna, Vojtiskova, Rychlikova \& Chutna (1963) and Mancini (1967) all failed to detect reactions between serum and spermatozoa by immune fluorescence. The present work re-examines the question of the naturally-occurring antibody, and characterizes it immunochemically.

The reaction between normal guinea-pig serum and homologous spermatozoa was studied using a two-step immune fluorescence procedure. Normal rabbit serum and rabbit immune sera to guinea-pig globulin, albumin and $\gamma$-globulin were conjugated with fluorescein and absorbed with liver-powder and guineapig spermatozoa. Conjugated rabbit antiserum to guinea-pig $\beta_{1 \mathrm{c}}$ was provided by Dr P. J. Lachmann. Smears of guinea-pig spermatozoa were fixed in alcohol and dried, incubated with the test serum for $20 \mathrm{~min}$ in a humid chamber at $37^{\circ} \mathrm{C}$, and then rinsed in four changes of phosphate buffer ( $\mathrm{pH} 7 \cdot 1$ ) for 20 min. Conjugated antiserum was then applied to the smear which was incubated and rinsed as before. The preparation was mounted in buffered glycerol and viewed under dark field illumination on a Zeiss Photomicroscope (Superpressure mercury lamp HBO 200W, Exciter filters BG 3 and BG 38, Barrier filter 47).

Normal serum from male or female guinea-pigs produced a bright acrosomal fluorescence on the spermatozoa, the limiting titre being approximately $1 / 64$. No non-specific reactions could be detected between conjugate and serum or between conjugate and spermatozoa (Table 1). Fluorescence was only slightly diminished when sera were absorbed with homogenates of guinea-pig liver, 
spleen, brain and kidney, but was diminished almost to zero after absorption by testis homogenate or spermatozoa, indicating specificity of reaction between serum and spermatozoa. The reaction between serum and acrosome described by previous workers was thus confirmed, and attempts were, therefore, made to characterize the serum fraction involved in the reaction.

TABLE 1

REAGTION OF AGROSOME WITH VARIOUS TEST SERA USING TWO-STEP IMMUNE FLUORESGENGE

\begin{tabular}{|c|c|c|}
\hline Test solution & Fluorescein conjugate & $\begin{array}{l}\text { Acrosomal } \\
\text { fluorescence* }\end{array}$ \\
\hline $\begin{array}{l}\text { Normal male guinea-pig serum } \\
\text { Normal female guinea-pig serum } \\
\text { Guinea-pig serum followed by } \\
\text { non-conjugated anti-guinea- } \\
\text { pig globulin } \\
\text { Buffered saline } \\
\text { Normal rabbit serum } \\
\text { Normal guinea-pig serum } \\
\text { Normal guinea-pig serum } \\
\text { Normal guinea-pig serum }\end{array}$ & $\begin{array}{l}\text { Anti-guinea-pig globulin } \\
\text { Anti-guinea-pig globulin } \\
\text { Anti-guinea-pig globulin } \\
\text { Anti-guinea-pig globulin } \\
\text { Anti-guinea-pig globulin } \\
\text { Anti-guinea-pig albumin } \\
\text { Normal rabbit serum } \\
\text { Non-conjugated fluorescein }\end{array}$ & $\begin{array}{l}+++++ \\
+++++ \\
++ \\
\pm \\
\pm \\
\pm\end{array}$ \\
\hline
\end{tabular}

* Brightness coded + to,++++ \pm is dubious fluorescence, - is negative.

The antispermatozoal factor in serum was precipitated by $50 \%$ ammonium sulphate, did not dialyse, was heat stable at $56^{\circ} \mathrm{G}$ for up to $2 \mathrm{hr}$ but not at $68^{\circ} \mathrm{C}$ for $\frac{1}{2} \mathrm{hr}$, and was not destroyed by $0.2 \mathrm{~m}-2$-mercaptoethanol. These properties suggest involvement of a serum protein. Guinea-pig serum was fraction-

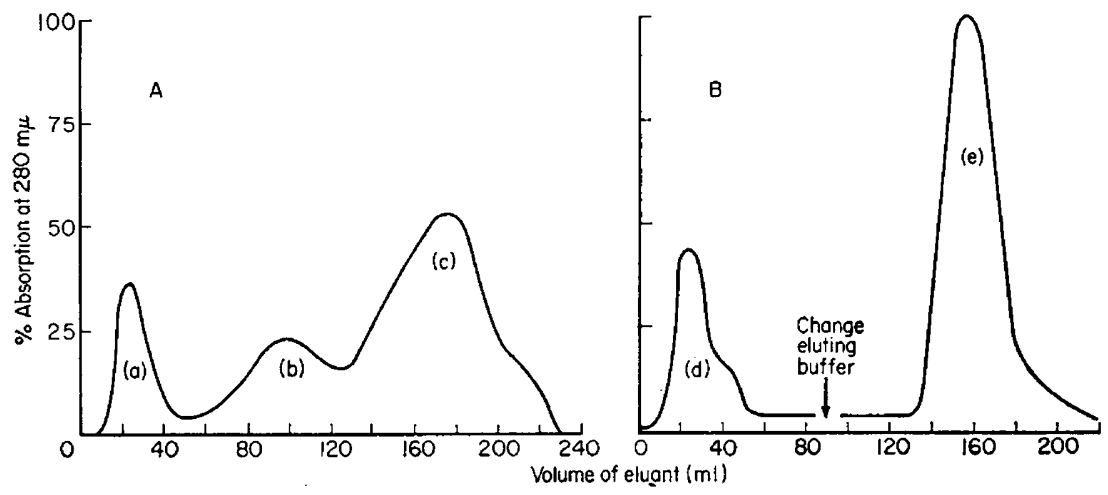

Text-fig. 1. Protein distribution after (A) Sephadex G-200 gel filtration and (B) DEAEcellulose ion exchange chromatography of guinea-pig serum. Peaks (a)-(e) concentrated and tested (see Plate 1).

ated by ultracentrifugation, G-200 Sephadex gel filtration, or two-step elution from DEAE-cellulose, and the activity in the fractions was measured by immune fluorescence. After ultra-centrifugation all antispermatozoal activity was in the $7 \mathrm{~S}$ fraction. The distribution of the activity in the fractions from Sephadex and DEAE-cellulose columns corresponds with that of $y$-globulin 


\section{PLATE 1}

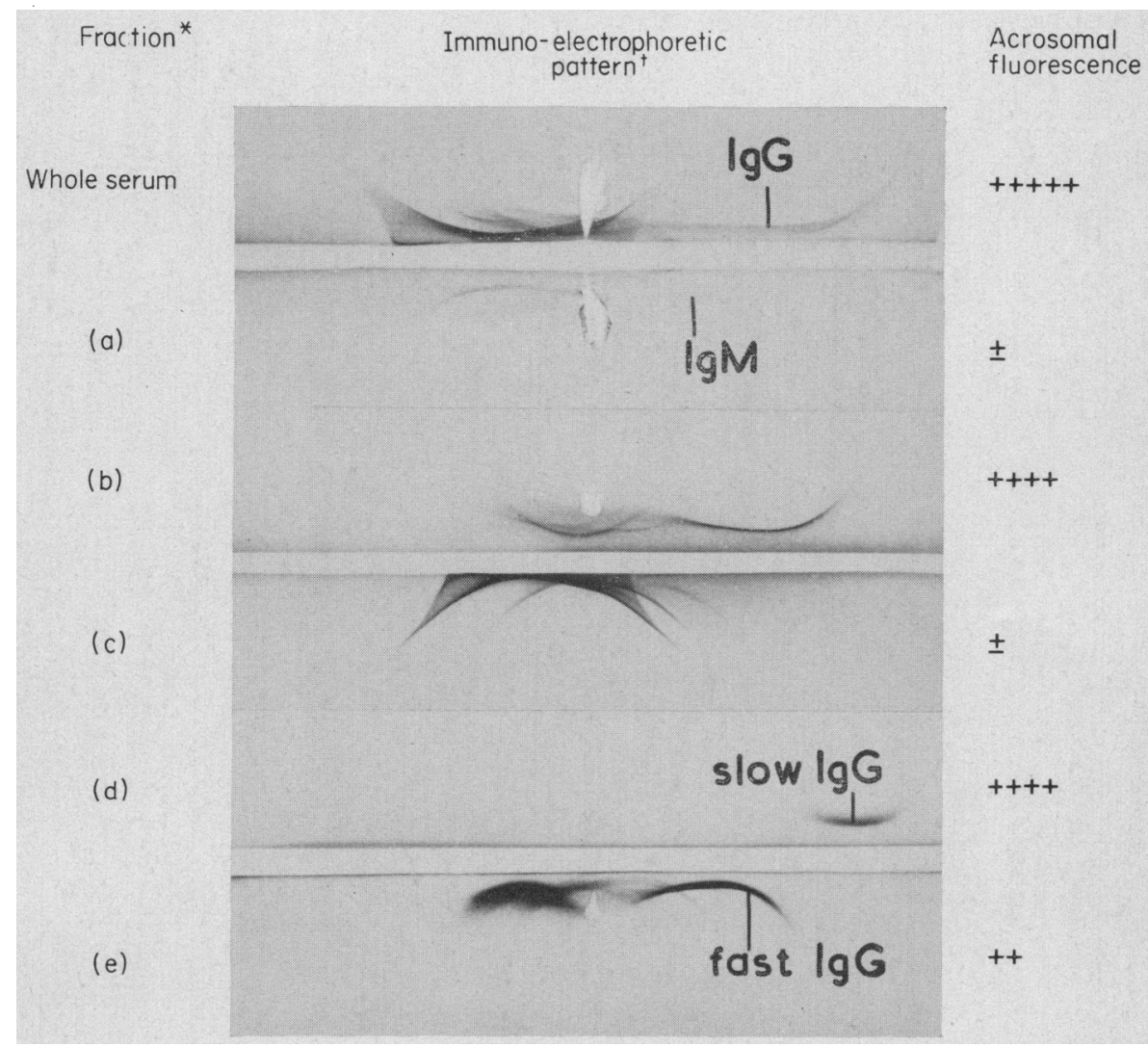

Immunoelectrophoretic analysis and anti-spermatozoal activity (as measured by acrosomal fluorescence) of the column fractions shown in Text-fig. 1 .

* See Text-fig. 1 .

$\dagger$ Using rabbit antiserum to guinea-pig serum. 
(IgG), and especially with slow $\gamma_{2}$-globulin $\left(\operatorname{IgG}_{2}\right)$ rather than fast $\gamma_{1}$-globulin $\left(\mathrm{IgG}_{1}\right)$ (Text-fig. 1, Plate 1). In confirmation of these findings, a conjugated rabbit anti-guinea-pig $\gamma$-globulin, shown to be monospecific by immunoelectrophoretic analysis, was tested on spermatozoa exposed to whole serum or to $\gamma$-globulin fractions of whole serum, and this also produced acrosomal fluorescence. All of these tests show that the antispermatozoal factor has the properties of an antibody.

The involvement of complement in the reaction between fresh serum and spermatozoa was examined using fluorescein-conjugated anti-guinea-pig $\beta_{1 \mathrm{c}}$ $\left(\mathrm{G}_{3}{ }_{3}\right.$ component of complement). Fluorescence was again confined to the acrosome, but was not detectable after treatment of the test serum with $\mathrm{NH}_{4} \mathrm{OH}$ to remove $\mathrm{C}_{4}^{\prime}$ and $\mathrm{C}_{3}^{\prime}{ }_{3}$, or after heating serum to $56^{\circ} \mathrm{C}$ for $1 \mathrm{hr}$ to destroy $\mathrm{C}_{1}^{\prime}$ and $\mathrm{C}^{\prime}{ }_{2}$. The results indicate that complement is fixed in the reaction between antibody and acrosome, agreeing with the earlier results obtained by complement fixation, lysis and mixed conglutination, which also detects fixed $\mathrm{C}_{3}^{\prime}$. It also agrees with the observations of Symons (personal communication), who used immune fluorescence to show that human $\beta_{1 \mathrm{C}}$ is fixed when human serum reacts with guinea-pig spermatozoa. In the guinea-pig, complement fixation is a property of slow $\gamma_{2}$-globulin, but not $\gamma_{1}$-globulin (Bloch, Kourilsky, Ovary \& Benacerraf, 1963).

The foregoing observations clearly establish the presence in normal serum of a specific, complement-fixing, $\gamma$-globulin antibody to the acrosome of spermatozoa, and it is presumably this antibody that was detected by previous workers, using a variety of techniques. The failure of Brown et al. (1963), Pokorna et al. (1963) and Mancini (1967) to detect the antibody is puzzling.

Natural antibodies against homologous or autologous antigens have been widely reported, but their origin and significance are far from clear (Boyden, 1966). The natural antibody lytic to spermatozoa and germinal cells could obviously cause damage if it gained access to the male reproductive tract. Normally, however, the concentration of $\gamma$-globulin in the secretions of the seminiferous tubules and in seminal plasma is less than one-hundredth that in serum (Johnson \& Setchell, in preparation). Much more protein is present in the female tract (Edwards, Talbert, Israelstam, Nino \& Johnson, 1968), and there is thus a possibility that some natural antibody may be present in uterine and oviducal fluids. A serum globulin, resembling the natural antibody against spermatozoa, is present on dead spermatozoa in the rabbit uterus (Symons, 1967).

I should like to thank Dr R. G. Edwards for valuable discussion, and the Medical Research Council and the Ford Foundation for financial support.

\section{REFERENCES}

BECK, J. S., Edwards, R. G. \& Young, M. R. (1962) Immune fluorescence techniques and the isoantigenicity of mammalian spermatozoa. F. Reprod. Fert. 4, 103.

Bloch, K. J., Kourilsky, F. M., Ovary, Z. \& Benacerraf, B. (1963) Properties of guinea-pig 7S antibodies. III. Identification of antibodies involved in complement fixation and haemolysis. F. $\exp$. Med. 117, 965. 
Boyden, S. V. (1966) Natural antibodies and the immune response. Adv. Immunol. 5, 1.

Brown, P. C., GlynN, L. E. \& Holborow, E. J. (1963) The pathogenesis of experimental allergic orchitis in guinea-pigs. F. Path. Bact. 86, 505.

Chang, M. C. (1947) The effects of serum on spermatozoa. F. gen. Physiol. 30, 321.

EDWARDs, R. G. (1960) Complement fixing activity of normal rabbit serum with rabbit spermatozoa and seminal plasma. F. Reprod. Fert. 1, 268.

Edwards, R. G. (1967) Antibodies and fertility. Sci. F. (Lond.), 3, 69.

Edwards, R. G., Talbert, L., Israelstam, D., Nino, H. V. \& Johnson, M. H. (1968) A diffusion chamber for exposing spermatozoa to human uterine secretions. Am. F. Obstet. Gynec. (In press).

Lachmann, P. J., Sele, K. W. \& Spooner, R. L. (1965) The mixed conglutination reaction. Immunology, 8,345 .

Mancini, R. E. (1967) Antispermatic antibodies in the human and animal male. In: Proceedings of the Eighth Conference of the International Planned Parenthood Federation, p. 350. Ed. R. K. B. Hankinson. I.P.P.F.

Merchnikoff, E. (1900) Récherches sur l'influence de l'organisme sur les toxines. Annls Inst. Pasteur, Paris, 14, 1.

Pokorna, Z., Vojtiskova, M., Rychlikova, M. \& Chutna, J. (1963) An isologous model of experimental autoimmune aspermatogenesis in mice. Folia biol., Praha, 9, 203.

Spooner, R. L. (1964) Cytolytic activity of the serum of normal male guinea-pigs against their own testicular cells. Nature, Lond. 202, 915.

Symons, D. B. A. (1967) Reaction of spermatozoa with uterine and serum globulin determined by immune fluorescence. F. Reprod. Fert. 14, 163. 